\title{
Influence of Allowances on Taking Log Deliveries
}

\section{Utjecaj veličine nadmjere na isporuku trupaca}

\author{
Original scientific paper • Izvorni znanstveni rad \\ Received-prispjelo: 6. 3. 2020. \\ Accepted-prihvaćeno: 14. 1. 2021. \\ UDK: $630 * 832.10 ; 630 * 832.15$ \\ https://doi.org/10.5552/drvind.2021.2015
}

\author{
(C) 2021 by the author(s). \\ Licensee Faculty of Forestry, University of Zagreb. \\ This article is an open access article distributed \\ under the terms and conditions of the \\ Creative Commons Attribution (CC BY 4.0) license.
}

\begin{abstract}
This paper deals with differences between the declared and actually supplied volume of round wood, which can be seen in the sawmill log yards in taking log deliveries. These differences usually mean the losses for the suppliers. Authors focus on the length accuracy of supplied logs. They start with a comprehensive manual checking of log deliveries (2639 logs) and with calibration of electronic measuring equipment (238 logs) made by an accredited laboratory. Authors analyse the origins of the differences, they quantify the volume "voluntarily" given by the suppliers in the form of oversized allowances and the volume of the losses caused by classifying the logs to a lower length group if the necessary allowance lengths are not observed (the volume is counted using e.g. $1 \mathrm{~m}$ shorter nominal length). The term "extra allowance" is introduced for allowances longer than wanted, and the dependences among the length of extra allowances, log diameter, volume of extra allowances and number of logs with too short allowance are defined. Losses caused by both of these defects (over-or under-sized logs) are counted and compared. If the log length value is exactly the required one or close to it (it means nominal length and required allowance), the measuring equipment can still measure a lower value because of the required precision of $1 \%$. Losses are also caused by reclassifying the logs to a lower group. Suppliers cut the logs longer (make "extra allowances") to ensure that the volume calculation is based on the right nominal length and not shorter. The research shows big differences between particular suppliers and their losses caused by extra allowances or reclassification of logs. The authors searched the optimum allowance in order to minimise the losses of the supplier. The results of the analysis give the following recommendations: for suppliers who do not use harvesters for felling and logging, it would be preferable to supply round timber in tree lengths due to the volume lost by reclassification. Today, however, this is not possible in most cases because large customers buy only logs because of technological reasons. Another aspect is the price, which is usually higher for raw material in logs. In the production of logs, it is preferable to increase the required $2 \%$ allowance by $4-5 \mathrm{~cm}$, if it is possible to produce the logs relatively accurately. If accuracy cannot be maintained, it is preferable to increase the allowance to about $7 \mathrm{~cm}$ (e.g. mountainous terrain, poor quality and curved timber, lack of experienced staff).
\end{abstract}

Keywords: log; round wood volume; delivery; allowance; loss

SAŽETAK • Tema rada su razlike između prijavljene i stvarno isporučene količine trupaca koje se događaju na stovarištima tijekom isporuke trupaca. Te razlike obično znače gubitke za dobavljače. Autori iznose svoja promišljanja o točnosti dužine isporučenih trupaca. Polazišta analize su rezultati ručnog mjerenja dimenzija velikog broja isporučenih trupaca (2639 komada) i rezultati dobiveni mjerenjima pri kalibraciji elektroničke mjerne opreme (rezultati mjerenja 238 trupaca) koju je obavio akreditirani laboratorij. Autori analiziraju izvor razlika, kvantificiraju volumen koji dobavljači ,dobrovoljno“ daju kao prevelike nadmjere te volumen gubitaka uzrokovanih razvrstavanjem trupaca u skupine manje dužine u slučajevima nedovoljno velikih nadmjera dužine trupaca (npr. volumen se izračunava uz pomoć metar kraće nominalne dužine). Uveden je pojam ,ekstranadmjere“ za nadmjere veće od potrebnih, definirane su relacije između veličine ekstranadmjere, promjera trupaca, volumena ekstranadmjere i broja trupaca s premalom nadmjerom dužine. Izračunani su i uspoređeni gubitci uzrokovani navedenim

\footnotetext{
${ }^{1}$ Author are researchers at Mendel University in Brno, Faculty of Forestry and Wood Technology, Department of Wood Science and Technology, Brno, Czech Republic.
} 
greškama u dimenzijama isporučenih trupaca (trupci prevelike ili premale dužine). Ako je dužina trupaca jednaka zahtijevanoj ili je blizu njezine vrijednosti (zahtijevana je dužina zbroj nominalne dužine i potrebne nadmjere), mjernom se opremom zbog tražene preciznosti od 1 \% ipak može izmjeriti manja dužina. Gubitci nastaju i zbog svrstavanja trupaca u skupinu manje dužine. Dobavljači režu trupce na veću dužinu (daju ekstranadmjere) kako bi osigurali da se volumen isporučenih trupaca računa sa stvarnom nominalnom dužinom, a ne s kraćom. Istraživanje je pokazalo da postoji velika razlika između pojedinih dobavljača i njihovih gubitaka koji su posljedica ekstranadmjera ili skraćivanja trupaca zbog nedovoljne nadmjere na duljinu trupaca. Autori su tražili optimalnu veličinu nadmjere dužine trupaca kako bi se umanjili gubitci dobavljača. Na temelju rezultata analize dane su ove preporuke: za dobavljače koji se ne koriste harvesterima za sječu, poželjna je isporuka oblovine u dužini stabla zbog gubitka volumena uzrokovanih reklasifikacijom. Međutim, danas to najčešće nije moguće jer veliki kupci kupuju trupce samo zbog tehnoloških razloga. Drugi je aspekt cijena, koja je obično veća za trupce kao sirovinu. Pri izradi trupaca poželjno je povećati nadmjeru na dužinu od $2 \%$, što je otprilike 4-5 cm, ako je trupce moguće relativno precizno izraditi. Ako se ne može postići točnost izrade trupaca, nadmjeru je poželjno povećati na $7 \mathrm{~cm}$ (npr. zbog planinskog terena, nekvalitetne i zakrivljene oblovine, nedostatka iskusnog osoblja).

Ključne riječi: trupac; volumen oblog drva; dostava; nadmjera; gubitak

\section{INTRODUCTION}

\section{UVOD}

The round wood volume is one of the most important parameters in the timber trade. Due to irregular body of the tree, the volume is determined approximately. Determined volume depends on the method of the measuring of the log parameters and also on the calculation method of the final volume. The differences between the actual and estimated volume present losses mainly for suppliers of round wood - forest companies.

Measuring can be electronic (2D or 3D) or manual. Differences in round wood measurements using electronic 2D and 3D systems and standard manual method were studied by several authors (Janák, 2007; Sauter et al., 2010). The calculation methods are mainly based on log diameter (top or mid) and the length of the whole log. The estimations also use shorter sections, which more or less take into account the form of the log (convergence and curvature). There are many works about this topic (Fonseca, 2005).

Filtration of the scanned data and its methods also affect seriously the calculated log volume (Hunková and Janák, 2014). If scanning is performed over the bark, estimation and subtraction of the bark thickness is the next factor seriously affecting the final log volume (Hunková and Janák, 2006; Duka et al., 2020). Many researchers and works were done in the field of log measuring and volume calculation, but to the best of our knowledge, none focused on the losses caused by precision of the length measuring of round wood.

Electronic measuring of the dimensions of round timber is quite common and it is used in the majority of sawmills. With the development of the electronic measurement of round timber, taking measurements of its dimensions was made more precise. This, however, eliminates the "human approach" or acceptable tolerance when taking deliveries of the round timber, which traditional manual inspections allowed. While working in a calibration laboratory and within the framework of collaboration with round timber suppliers, data from measurements taken of the length of spruce round timber in the Czech Republic were collected. The data were subsequently analysed. The analysis was mainly focused on the degree of allowances with respect to the length of logs and round timber.

The allowances were excessive compared to the nominal length required to produce sawn timber of a particular length in the required quality. If the allowance is not observed, the logs are placed into a lower length grade upon taking electronic log deliveries. Then, the volume paid for by the customer to the supplier corresponds to a shorter nominal length. In the Czech Republic, length grades of $0.25 \mathrm{~m}$ or $0.5 \mathrm{~m}$ are standard for coniferous raw material. Large customers usually grade length $1 \mathrm{~m}$ increments. In such cases, the suppliers may suffer relatively large losses. Therefore, suppliers are forced to increase the allowance to ensure that the logs are included in the expected length grade, even with minor inaccuracies in measuring or cutting.

In the Czech Republic and its neighbouring countries, no allowance is added to the volume of round timber. It, therefore, always causes a loss for the supplier. This is due to the requirement to supply round timber at such a length that enables to produce timber of a given nominal length. The rule is based on the past when sawing residues were considered waste. Today, however, almost everything can be used or sold. Large allowances are therefore an advantage for sawmills. However, too high allowance may cause difficulties in the grading of round timber by use of sorting lines of large plants, unless they are equipped with a shortening device. Depending on the size of boxes, they also require the supplier to maintain a maximum allowance length.

Today, a $2 \%$ allowance is commonly required in the Czech Republic. This is set out in the Recommended Rules for Measuring and Sorting of Wood (Wojnar et al., 2008). These are non-binding rules, but they are the result of negotiations between suppliers and customers, and most tend to adhere to them.

Length allowance is also determined by the Czechoslovak state standard ČSN 480050 Rough wood. Basic and common regulation of 1992. Here, the length allowance is specified at $1 \%$, but not more than $0.10 \mathrm{~m}$. The standard remains valid, but is not often applied in practice. 
Since none of these regulations is binding, allowances may also be specified in sales contracts in another way (e.g. at least $5 \mathrm{~cm}$ of allowance for $4 \mathrm{~m} \mathrm{logs}$ ) or other values may be required (e.g. $3 \%$ for a long log).

Length is measured to the nearest centimetre. During production at the supplier's, length is usually measured by a tape measure or harvester, and occasionally by a sorting line (the number of forest handling and distribution warehouses is very small today). At the customer's, the length can again be measured by tape measure. Today, most round timber, however, is scaled using sorting lines equipped with electronic measuring equipment.

The accuracy of taking measurements by electronic measuring equipment is required to be at least $1 \mathrm{~cm}$ according to EN 1309-2:2006 Round and sawn timber Method of measurement of dimensions - Part 2: Round timber - Requirements for measurement and volume calculation rule. The maximum permissible deviation in length measurement is $1 \%$ according to the Recommended Rules for Measuring and Sorting Wood. In some countries, it is supplemented by a maximum deviation of $5 \mathrm{~cm}$. Similarly, this is usually specified in the agreements between suppliers and customers.

The accuracy of electronic measurements is influenced by other factors besides the actual accuracy of the equipment. These include the movement of the round timber on the conveyor during measurement, inclined fronts, curvature of the logs, torn fibres or icing on the surface. Most of these factors result in the measurements being longer than the actual length.

The accuracy of taking log measurements in a forest is affected in a similar manner. Here the main factors include: the measurement method used (tape measure, harvester), working conditions (e.g. forest felling) and the human factor.

The differences between manual and electronic measurements were investigated in the Czech Republic between 2000 and 2007. Janák et al. (2005) made the following findings:

Deviations in taking 2D measurements: length is slightly but evenly underestimated, i.e. electronic measurement results show lower values. The average deviation was $-0.7 \mathrm{~cm}$, with a minimum of $-6 \mathrm{~cm}$ and a maximum of $+8 \mathrm{~cm}$. On the other hand, the average with the 2D electronic system is slightly higher, but also uniform. Due to the fact that volume is calculated from nominal length, and the shifting of logs to the lower length grade due to length deviation rarely occurs, the influence of lower electronically measured length values on volume is minimal. The influence of higher electronically measured average values prevails, therefore volume values are slightly overestimated.

Deviations in taking 3D measurements: Length is slightly but evenly overestimated, i.e. electronic measurement results show higher values $(+0.6 \mathrm{~cm}$ on average, with a minimum of $-6 \mathrm{~cm}$ and a maximum of +17 $\mathrm{cm})$. On the other hand, the average given by the electronic system is slightly lower, but also uniform. Due to the lower influence of electronically measured values of length on volume, the influence of lower elec- tronically measured diameter values prevails. The values of volume are therefore slightly undervalued (Janák et al., 2005).

In the bachelor thesis by Prribyl (2005), the accuracy of sawed logs in electronic taking deliveries was studied. Accuracy was assessed for selected logs (100 pcs) that have passed the measuring frame five times in different pivot positions. None of the logs in these five measurements showed conformity with all monitored dimensions (mid- and top diameter, measured and recorded length). The differences were 1-3 cm for length measurement, while the error in thickness determination was mostly $1 \mathrm{~cm}$. It should be noted that the values were already rounded in accordance with current practice, i.e. values after the decimal point were not considered. In such case, an actual difference of $2 \mathrm{~mm}$ may result in a 1 cm error (e.g, 22.9 and $23.1 \mathrm{~cm}$ correspond to 22 and 23 $\mathrm{cm}$ after cut off). The thesis further summarised some of the factors that influence takeover and suggested several ways to limit the effect of these factors.

\section{MATERIALS AND METHODS}

\section{MATERIJALI I METODE}

The analysis was focused on losses due to increasing the length allowance for suppliers (i.e. a profit of raw material for customers). The objective was to find out what increase in allowance was acceptable for suppliers, while reducing the possibility of shifting logs between shorter pieces (and the associated loss of raw material delivered), but not causing the same or higher loss of raw material. Therefore, a theoretical volume and a percentage of losses were calculated. This was compared with practical data.

\subsection{A description and marking of analysed parts of logs}

2.1. Opis i obilježavanje analiziranih dijelova trupaca

A description and marking of the analysed parts of logs is shown in Figure 1.



Figure 1 A description and marking of the analysed parts of $\operatorname{logs}\left(L_{\mathrm{N}}-\right.$ nominal length, $L_{\mathrm{A}}-$ length allowance, $L_{\mathrm{E}}-$ extra length allowance, $L_{\mathrm{S}}-$ length of $\log$ cut step, $D_{\mathrm{M}}-$ mid $\log$ diameter (in the middle of the nominal length), $D_{\mathrm{A}}$ - mid-diameter of the required allowance $(2 \%), D_{\mathrm{E}}$ - mid-diameter of the extra allowance, $D_{\mathrm{S}}$ - mid-diameter of the cut step)

Slika 1. Opis i označivanje analiziranih dijelova trupaca $\left(L_{\mathrm{N}}\right.$ - nominalna dužina, $L_{\mathrm{A}}$ - nadmjera na dužinu, $L_{\mathrm{E}}-$ ekstranadmjera na dužinu, $L_{\mathrm{S}}-$ dužina koraka rezanja trupca, $D_{\mathrm{M}}$ - srednji promjer trupca na sredini nominalne duljine, $D_{\mathrm{A}}-$ srednji promjer potrebne nadmjere, $2 \%, D_{\mathrm{E}}$ - srednji promjer ekstranadmjere, $D_{\mathrm{s}}$ - srednji promjer unutar koraka rezanja) 


\subsection{Data from practice}

\subsection{Podatci iz prakse}

The input data came from two sources:

- check measurements of deliveries taken in 2013 and 2015 ,

- measurements carried out during calibration of the measuring equipment in sawmills.

\subsubsection{Check measurement of deliveries in $\mathbf{2 0 1 3}$} and 2015

2.2.1. Kontrolna mjerenja isporuka u 2013. i 2015. godini

As part of the check measurements, data from delivery notes, sawmills and check manual measurements were compared. The manual measurements were performed in accordance with the Recommended Rules for Measuring and Sorting Wood in the Czech Republic 2008. Lengths were measured using a tape measure as the shortest distance between the ends with an accuracy of $1 \mathrm{~cm}$.

$1,380 \operatorname{logs}$ were inspected in 2013, which represents $462.29 \mathrm{~m}^{3}$ of wood. 7 deliveries with a total of $1,084 \operatorname{logs}$ and 8 deliveries with $296 \operatorname{logs}$ were analysed. In 2015, 1,259 logs $\left(384.99 \mathrm{~m}^{3}\right)$ were measured.

The number of logs with an allowance of less than or equal to the required $(2 \%)$ was determined from the check measurements. For logs with larger allowances, the volume of excess allowance was calculated. For logs having a smaller allowance and being rightfully assigned to a lower length category, the volume corresponding to the loss was calculated. The Huber method was used for calculating the volume (for more details, see Theoretical Analysis of Losses). The findings were expressed as a percentage for each individual delivery.

\subsubsection{Calibration measurements}

2.2.2. Kalibracijska mjerenja

Measurements taken during calibration are more accurate. For the calibration of each piece of equipment, 25-30 logs with straight faces and without any torn fibres were selected. The length of each log was measured in four positions, and the values determined to the nearest millimetre were then averaged. During the taking of electronic measurements, all logs were measured 3 times. For the purposes of this work, values from the calibration of 10 different pieces of equipment performed in 2018 were used. Data from both 2D and $3 \mathrm{D}$ measurements were included. In total, $238 \mathrm{logs}$ at lengths of 3, 4 and $5 \mathrm{~m}$ were measured by hand and three times electronically. During these measurements, the thickness of the logs was not measured, so the volume of the checked round timber could not be determined.

Therefore, 714 measurements were available to determine deviations on the measuring devices. For these data, the difference between the manually measured lengths (an average of four measurements) and each length measured by the measuring device was calculated. Differences were expressed in both absolute and percentage terms and a basic statistical analysis was performed.
In addition, 238 values were used to determine the additional sizes. The values were divided into three groups: a log group with an allowance of exactly $2 \%$, a group with a smaller allowance and a group with an extra allowance. In the last two groups, a statistical analysis of the occurrence and magnitude of these values was carried out both in absolute values and as a percentage.

How many times the log could hypothetically be moved to a shorter length grade was evaluated separately. For this purpose, logs with a manually measured length that exactly met the requirements (i.e. with an allowance of $2 \%$ ) and larger were selected from the data. The manually measured lengths were then compared to the electronically measured lengths and, in case of undersizing, moved to a lower length grade. This is only a hypothetical re-assignment, as no takeover data were available for calibrations, but only inspection reports for the calibration.

\subsection{A theoretical analysis of losses}

2.3. Teorijska analiza gubitaka

In the first phase, the volumes of logs were modelled for mid-log diameter ranging from $10-60 \mathrm{~cm}$ by 1 $\mathrm{cm}$ and lengths of 3-14 $\mathrm{m}$ by $1 \mathrm{~m}$. Volumes were determined for logs of nominal length (precise, with no allowance), as well as for the logs that represented a $2 \%$ allowance, and finally for logs with an allowance greater than $2 \%$ by $1-10 \mathrm{~cm}$ with a $1 \mathrm{~cm}$ diameter interval.

The volumes were calculated using the Huber method (1:1 ratio). In this method, the volume of the $\log$ is simplified to the cylinder volume. The input parameters are the nominal length $L_{N}$ and mid-diameter of round timber $D_{\mathrm{M}}$. Although this method deviates from the real volume values, it is most commonly used in practice and does not have a major effect on the theoretical analysis in terms of allowances.

For this calculation, the mid-diameter is necessary. This was based on the commonly used spruce wood taper of $1 \mathrm{~cm} / 1 \mathrm{~m}$.

Subsequently, the percentage of volume of voluntary extra allowance for logs of a nominal length was calculated, again for mid-diameter in the range of $10-60 \mathrm{~cm}$ and a length of 3-14 m. This was then displayed in the graph. For the lengths of logs most commonly occurring in practice, graphs of the extra allowance volume to the mid-diameter of the logs and the length of extra allowance were created.

The next step involved calculating the volume of the part of log that corresponds to the log cut step (most often, $1 \mathrm{~m}$ in the Czech Republic). The calculation was carried out for the thinner part of the log using the $\mathrm{Hu}-$ ber method and with an assumed diameter interval of 1 $\mathrm{cm} / 1 \mathrm{~m}$. Again, a recalculation to the percentage of this volume compared to the volume of the whole log and graphs of dependencies were compiled. Again, the above ranges were considered, but the results were only shown for values most common in practice.

From this analysis, the values of losses, occurring in both cases, were then derived and an assessment 
of the advantage/disadvantage of the preparation of logs with different sizes of extra allowance under the given production conditions was made.

\section{RESULTS AND DISCUSSION}

\section{REZULTATI I RASPRAVA}

\subsection{Results from calibration measurements} 3.1. Rezultati kalibracijskih mjerenja

\subsubsection{Deviations in electronic measuring equipment \\ 3.1.1. Odstupanja elektroničke mjerne opreme}

From the data obtained during the calibration, deviations in the electronic measurements versus the manual measurements were first determined. Individual electronic measurements were compared with the average of the four manual measurements of each log. Most of the deviations were positive, as also shown by the results of the statistical analysis, presented by the bar graph in Figure 2. The figure shows the deviations in centimetres (lengths of 3,4 , and $5 \mathrm{~m}$ were represented). The deviations can be converted to percentage evaluation. The percentage evaluation shows that even outliers (-0.91 and 0.96) do not exceed the tolerance of $\pm 1 \%$. Most of the deviations, i.e. $87 \%$, were positive. The average value of all measurements was $1 \mathrm{~cm}$; the percentage taking into account the length was $0.24 \%$. It can be stated that all tested devices slightly overestimated the length.

It was also analysed in how many cases an inaccurate measurement could cause a log with sufficient allowance to be moved to a lower length grade. This would happen in 22 out of 714 cases if there was no tolerance. This equates to $9 \operatorname{logs}$, which were in one or two measurements out of three underestimated by 1 to $2 \mathrm{~cm}$. Based on the manual measurements, 5 of them had an allowance of exactly $2 \%$ and 4 were $1 \mathrm{~cm}$ longer. In total, this error occurred in $3 \%$ of all measurements, but in $32 \%$ of the measurements of individual logs with an exact allowance or with an allowance only $1 \mathrm{~cm}$ larger (23 logs, i.e. 69 measurements).

For performing calibrations, logs without any major defects, straight and with perpendicular cuts,

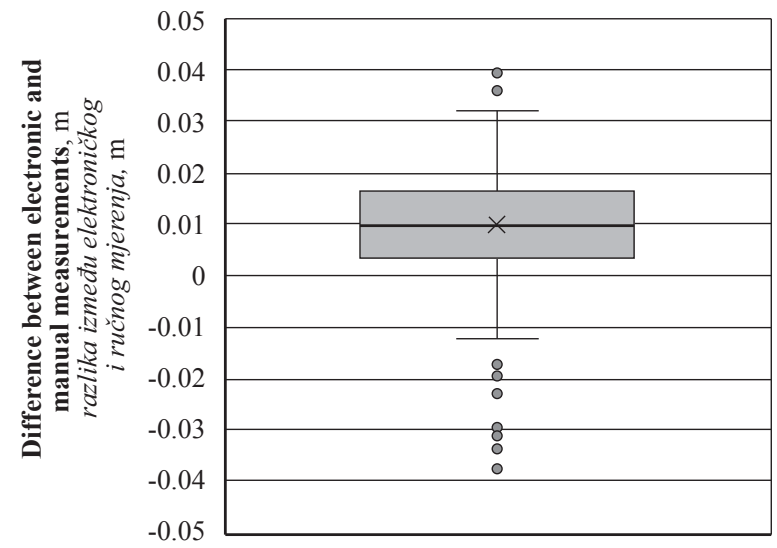

Figure 2 Difference between electronic and manual measurement evaluated from calibration measurements Slika 2. Razlika između elektroničkoga i ručnog mjerenja procijenjena na temelju kalibracijskih mjerenja were deliberately selected. Also, the logs were not frozen and conveyor dirties were not common. This eliminated the effects of log defects and helped to assess possible defects in the equipment. However, most of these "unfavourable" factors that occur in normal practice affect taking measurements showing positive values (longer lengths than those actually measured).

It should also be pointed out that data from calibrations carried out at regular intervals on measuring devices by customers who take quality check measurements were used. The measurement results of these devices depended on the software, mechanical layout and overall system settings. Therefore, it cannot be said with any degree of certainty that all facilities in the Czech Republic operate with the specified level of accuracy. If a supplier has doubts about the accuracy of the measurements taken, the customer should be advised to perform an independent calibration of the equipment.

The fact that the measuring devices slightly overestimate the actual length is partly consistent with the findings by Janák et al. (2005). According to the results of the measurements taken at that time, the 3D measuring systems tended to overestimate, while 2D systems tended to underestimate the values. This time, all inspected systems overestimated the values. At the same time, the variance of deviations from the mean value were significantly lower, and even the outliers did not deviate from the allowed $1 \%$ error tolerance.

\subsubsection{Length allowances}

3.1.2. Nadmjera dužine

Length measurements taken during calibration were further analysed from the measured data. The input values consisted of manually measured lengths, i.e. lengths unaffected by the accuracy of the measuring equipment. The average was calculated from 4 measurements with an accuracy of millimetres.

Of all 238 logs, only 4 logs were shorter (i.e. 1.68 $\%$ ). The difference between the length including the desired addition and the measured value was 1 and $2 \mathrm{~cm}$.

Conversely, an extra allowance was found in 232 $\operatorname{logs}(97.48 \%)$. Here, the average value of the differ-

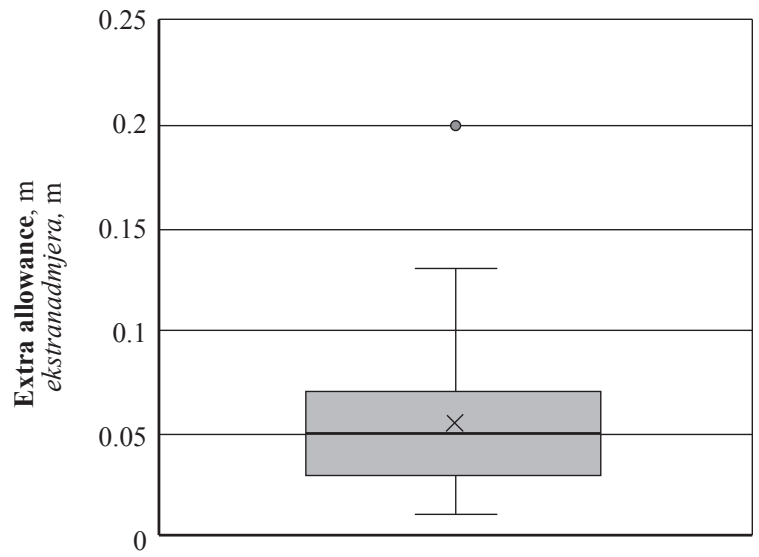

Figure 3 Extra allowances of logs estimated during calibration measurements

Slika 3. Ekstranadmjere dužine trupaca utvrđene tijekom kalibracijskih mjerenja 
ence between the desired length and the measured value was $5.5 \mathrm{~cm}$, with the median being $5 \mathrm{~cm}$. The biggest difference was $19 \mathrm{~cm}$ (found in a $4 \mathrm{~m} \mathrm{log}$ ). However, this was an exceptional value; the maximum difference was $13 \mathrm{~cm}$ (for a $3 \mathrm{~m} \mathrm{log}$ ) - see Figure 3 .

The results show that suppliers typically lean towards the safe side and in most cases deliver logs with a length greater than required. No log diameter data was included in the calibration measurements; therefore, no volume loss evaluation could be performed.

\subsection{Data from check measurements of deliveries} 3.2. Podatci kontrolnih mjerenja isporuka

\subsubsection{Check measurements 2013 - round timber}

\subsubsection{Kontrolna mjerenja u 2013. godini - oblo drvo}

The data from check measurements in 2013 were used to assess the size of allowances in standard round timber deliveries and the resulting volume losses. An analysis was performed separately for logs at basic and associated lengths (long round timber). 7 deliveries with a total of 1,084 logs and 8 deliveries with $296 \operatorname{logs}$ were analysed.

The deliveries of long round timber examined in this selection represented a total volume of $252.51 \mathrm{~m}^{3}$. The average length of extra allowance was $20 \mathrm{~cm}$, as shown in the graph in Figure 4. On average, extra allowances represented a loss of $1.84 \%$, i.e. about 0.016 $\mathrm{m}^{3}$ of wood per log. However, the average was slightly adversely affected by outliers; a median of $0.013 \mathrm{~m}^{3}$ is more suitable for the characteristics of this sample. From the total volume of the entire selection of round timber, the volume of the extra allowances makes up at most 1.5 and $2.3 \%$, with the average being $1.95 \%$.

When evaluating the deliveries separately (Figure 5), a slight deviation can be observed in one delivery (indicated by the letter $\mathrm{C}$ ) in which the average allowance was $26 \mathrm{~cm}$. When recalculating the percentage of the entire round timber volume, this represents $2.45 \%$.

Of the analysed $\operatorname{logs}$, only 7 were undersized $(2.3$ $\%$ of the logs) - see Table 1 . In terms of volume, this amounted to $4.640 \mathrm{~m}^{3}$, i.e. $0.42 \%$ of the volume of all deliveries together. The average difference between the required allowance and the actual one was $13 \mathrm{~cm}$, but



Figure 4 Box chart of extra allowance of round timber Slika 4. Grafikon ekstranadmjera za oblo drvo

the data set was too small for making a statistical evaluation. The value ranged from 1 to $21 \mathrm{~cm}$.

It was determined that in one case the length was evaluated incorrectly and a $\log$ with an exact allowance (10.2 $\mathrm{m})$ was moved to a lower length grade $(9 \mathrm{~m})$. The customer thus did not pay for $0.110 \mathrm{~m}^{3}$ of wood $(0.3$ $\%)$. In the overall evaluation in terms of volume, this represents only $0.04 \%$ of the sum of the volume of all long pieces of round timber.

\subsubsection{Check measurements 2013 - logs}

3.2.2. Kontrolna mjerenja u 2013. godini - trupci

In the data set containing logs of basic lengths, an analysis of the allowance larger than the required $2 \%$ was also performed separately (Figure 6). The unnecessary excess allowance amounted to $2.543 \mathrm{~m}^{3}$ of wood, i.e. $1.21 \%$ of the total volume of all deliveries $\left(209.78 \mathrm{~m}^{3}\right)$. Most often (50\% of the time), logs were delivered 3-7 cm longer (the average being 5.2 with a median of $5 \mathrm{~cm}$ ). In $95 \%$ of the cases, values ranged from 1 to $13 \mathrm{~cm}$, but in extreme cases, allowances of more than $20 \mathrm{~cm}$ were also found. In percentage terms, the extra allowance represented an average of $1.40 \%$ of the volume of the whole log.

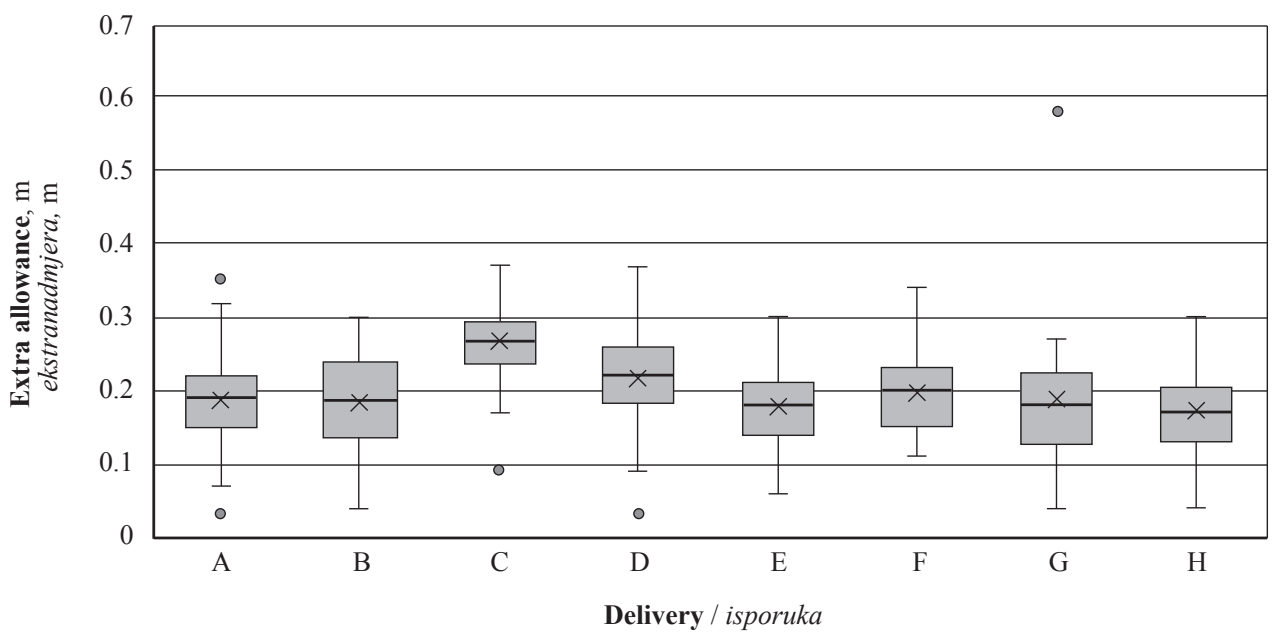

Figure 5 Box chart of extra allowance of round timber evaluating deliveries separately

Slika 5. Grafikon ekstranadmjera za oblo drvo određenih prema isporukama oblog drva 
Table 1 Analysis of round timber deliveries

Tablica 1. Analiza isporuke oblog drva

\begin{tabular}{|c|c|c|c|c|c|c|c|c|c|}
\hline 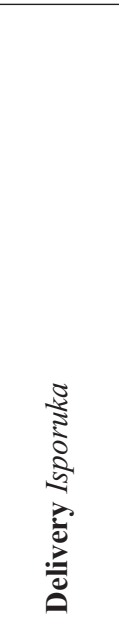 & 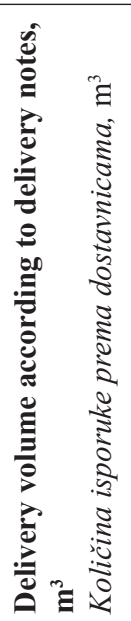 & 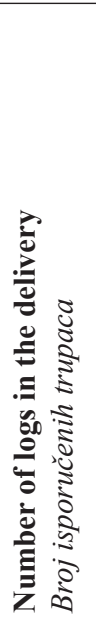 & 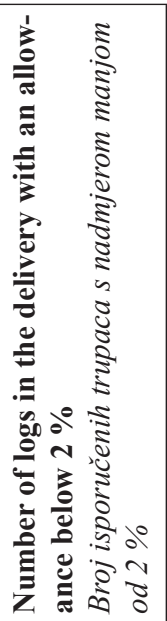 & 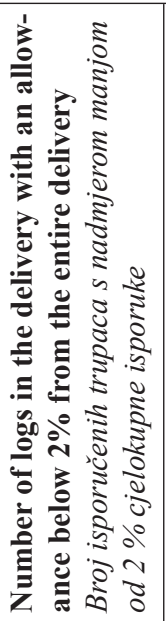 &  & 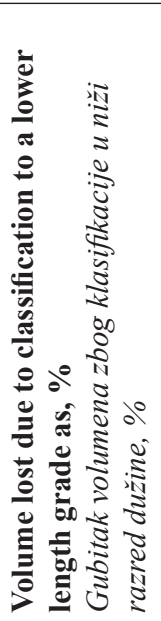 & 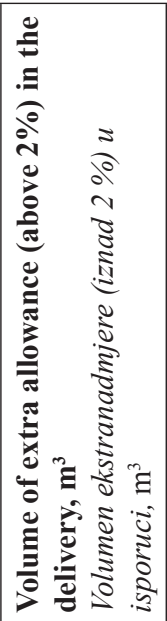 & 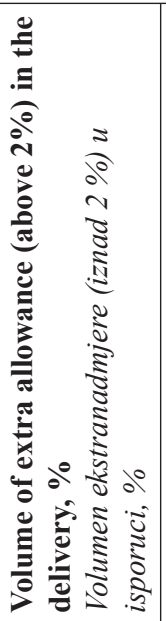 & 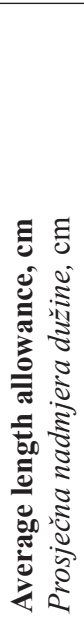 \\
\hline A & 35.04 & 38 & 2 & 5.26 & 0.227 & 0.65 & 0.602 & 1.72 & 17.9 \\
\hline B & 37.95 & 31 & 3 & 9.68 & 0.632 & 1.67 & 0.529 & 1.39 & 18.1 \\
\hline $\mathrm{C}$ & 29.70 & 59 & 1 & 1.69 & 0.073 & 0.25 & 0.722 & 2.43 & 26.6 \\
\hline $\mathrm{D}$ & 29.05 & 36 & 0 & 0.00 & 0.000 & 0.00 & 0.643 & 2.21 & 21.5 \\
\hline $\mathrm{E}$ & 25.32 & 26 & 0 & 0.00 & 0.000 & 0.00 & 0.427 & 1.69 & 17.7 \\
\hline $\mathrm{F}$ & 34.60 & 36 & 0 & 0.00 & 0.000 & 0.00 & 0.640 & 1.85 & 19.6 \\
\hline G & 33.03 & 27 & 1 & 3.70 & 0.123 & 0.37 & 0.557 & 1.69 & 18.6 \\
\hline $\mathrm{H}$ & 27.82 & 46 & 0 & 0.00 & 0.000 & 0.00 & 0.520 & 1.87 & 17.0 \\
\hline $\begin{array}{c}\text { Total } \\
\text { Ukupno }\end{array}$ & 252.51 & 299 & 7 & 2.34 & 1.055 & 0.42 & 4.640 & 1.84 & 19.6 \\
\hline
\end{tabular}

Similarly to the evaluation of round timber at full lengths, the log deliveries did not show any larger statistical differences. This is evident from the box graph in Figure 7. Slight deviations were found in delivery $\mathrm{O}$, where the median value of allowance was $10 \mathrm{~cm}$ larger than required. On average, the log volume in this delivery was larger by $2.1 \%$.

Of the 1,084 logs analysed, mostly 4 and $5 \mathrm{~m}$ in length, 76 logs had an allowance that did not meet the requirement of $2 \%$ (i.e. $7 \%$ of the $\operatorname{logs}$ ). When these logs were moved to a smaller length grade, there was a loss of $3.096 \mathrm{~m}^{3}$ out of a total of $209.78 \mathrm{~m}^{3}$, i.e. $1.35 \%$.

The difference between the setpoint and the measured value most often ranged from 1 to $3 \mathrm{~cm}$ (see



Figure 6 Box chart of extra allowance of logs in 2013 Slika 6. Grafikon ekstranadmjera za trupce u 2013.
Figure 8). Although not a big error, it always meant a classification to a lower length grade and thus a loss of volume corresponding to a volume of $1 \mathrm{~m}$.

The evaluation of individual deliveries revealed certain differences in the accuracy of log production (Table 2). In two deliveries, there were no undersized logs. For the remaining 5, deviations from the requirement varied. The largest number of logs with an insufficient allowance was found in delivery I (36 out of 164 logs). When these logs were moved to a smaller length grade, there was a loss of $1.118 \mathrm{~m}^{3}$, which represents a loss of $4.42 \%$ from the total $25.29 \mathrm{~m}^{3}$ of the delivery.

A special case was delivery O. Here, a large amount of wood $(1.77 \%)$ was supplied with an allowance larger than $2 \%$. At the same time, 3 pieces did not have enough allowance, which represents a loss of 0.88 $\%$. The accuracy of log length was very different. This could be due to poor terrain conditions or the inexperience of the cutting operator.

The best results in terms of accuracy of cuts were found in delivery $\mathrm{K}$. Here, the allowances were the smallest of all the evaluated deliveries and the supplier "donated" only $0.7 \%$ of the wood volume to the customer. In addition, the delivery did not include any undersized logs.

Total volume losses of the deliveries caused due to extra allowances and due to classification to a lower length grade are visible in the graph in Figure 9. It was not possible to establish the relationship between the accuracy of cutting and losses because of the small number of deliveries. 


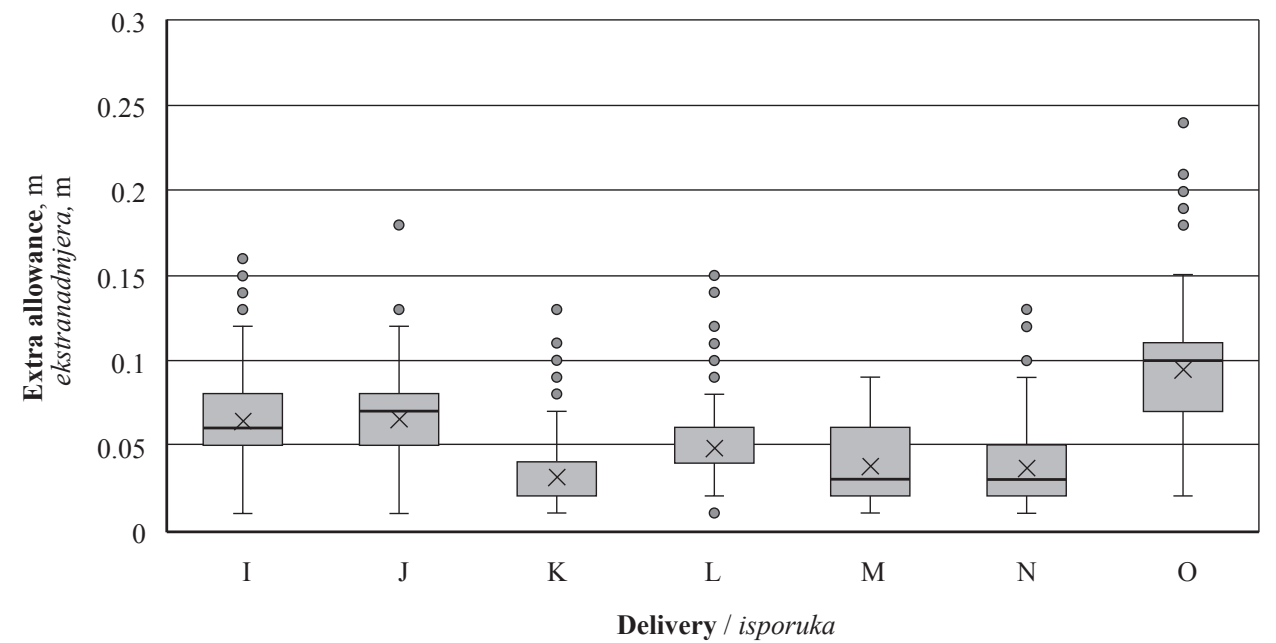

Figure 7 Box chart of extra allowance of logs in 2013 evaluating the deliveries separately Slika 7. Grafikon ekstranadmjera dužine trupaca prema njihovim isporukama u 2013.

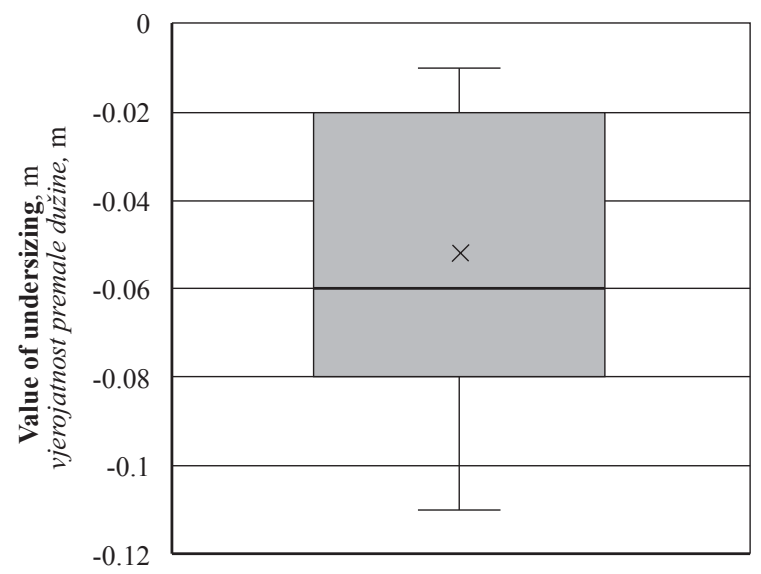

Figure 8 Box chart of the difference between the required allowance and measured value of undersized logs in 2013 Slika 8. Grafikon razlike između potrebnih nadmjera i izmjerene vrijednosti dužine kraćih trupaca u 2013.

\subsubsection{Check measurements 2015 \\ 3.2.3. Kontrolna mjerenja u 2015. godini}

In 2015, a similar check measurement was carried out, but only the deliveries of logs were available. Long round timber was not evaluated. The results are similar to those in 2013, and therefore graphs with detailed results will not be shown. The average extra allowance length was $4.5 \mathrm{~cm}$ (a median of $5 \mathrm{~cm}$ ). Within a delivered volume of $384.99 \mathrm{~m}^{3}$, this represents 3.782 $\mathrm{m}^{3}$, i.e. less than $1 \%$.

The number of undersized logs was 24 out of a total of 1,259 . When these logs were moved to a smaller length grade, there was a loss of $0.57 \%$ in volume. Of the 14 deliveries reviewed, only 3 were without a single undersized log. The worst result was found in delivery $i$, in which 7 out of 60 pieces were shorter, and the volume loss due to reclassification was $2.9 \%$.

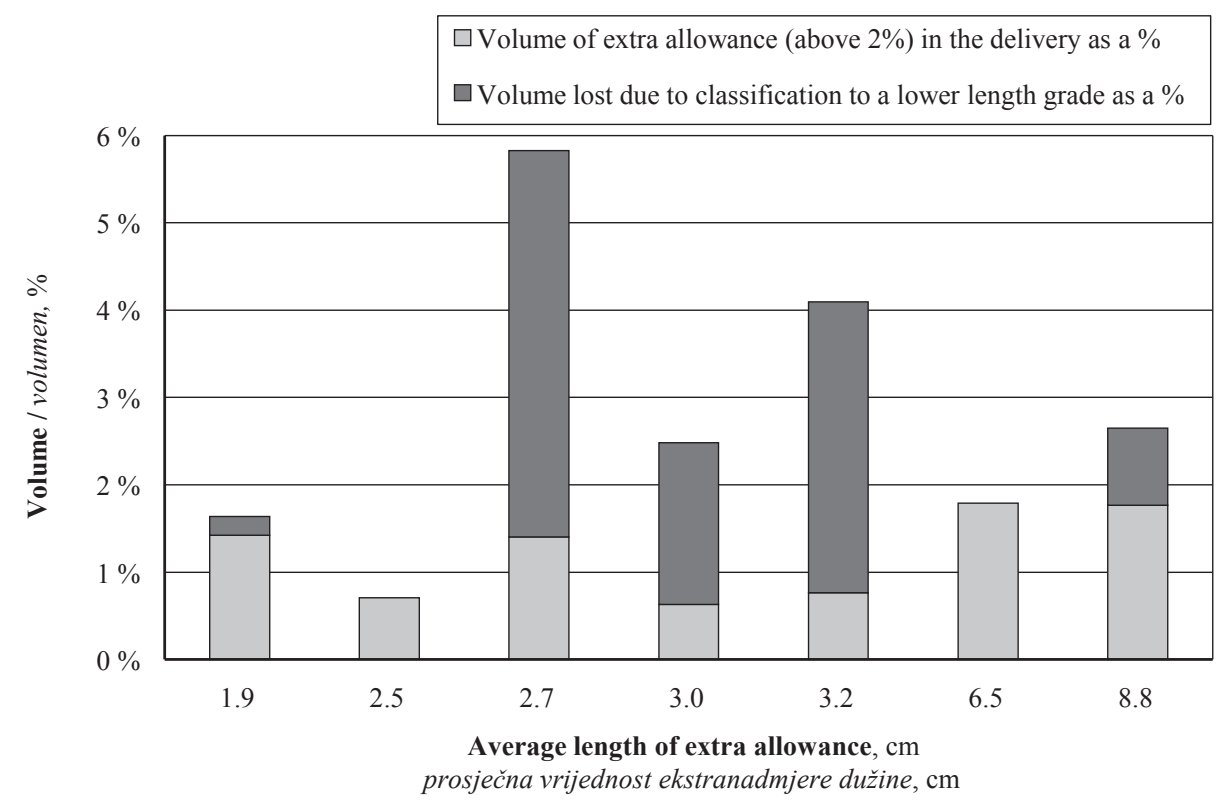

Figure 9 Total losses of wood volume in individual log deliveries

Slika 9. Ukupni gubitci volumena drva u pojedinačnim isporukama trupaca 
Table 2 Analysis of log deliveries in 2013

Tablica 2. Analiza isporuke trupaca u 2013.

\begin{tabular}{|c|c|c|c|c|c|c|c|c|c|}
\hline  & 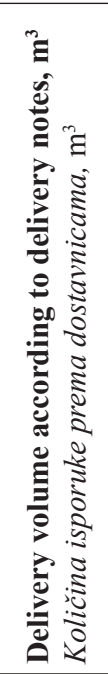 & 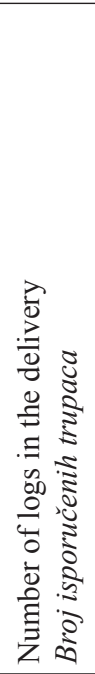 & 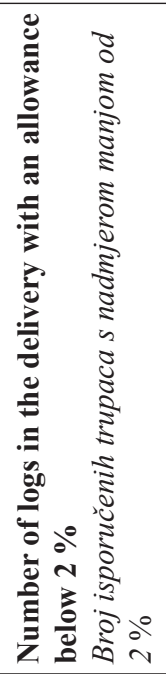 & 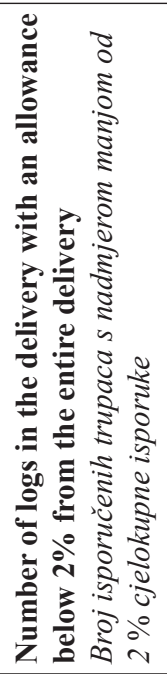 &  & 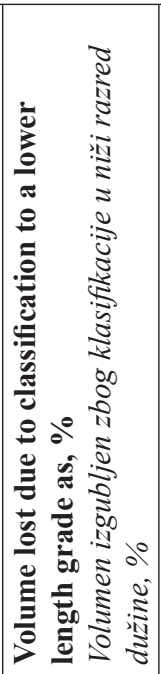 &  & 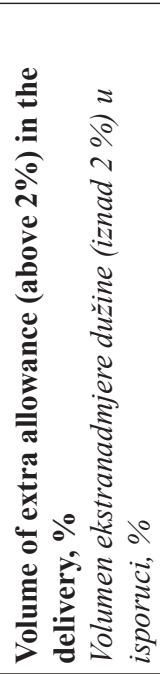 & 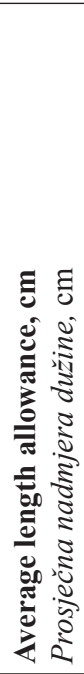 \\
\hline $\mathrm{I}$ & 25.29 & 164 & 36 & 21.95 & 1.118 & 4.42 & 0.355 & 1.40 & 2.7 \\
\hline $\mathrm{J}$ & 29.60 & 187 & 0 & 0.00 & 0.000 & 0.00 & 0.531 & 1.79 & 6.5 \\
\hline $\mathrm{K}$ & 29.53 & 170 & 0 & 0.00 & 0.000 & 0.00 & 0.210 & 0.71 & 2.5 \\
\hline $\mathrm{L}$ & 30.52 & 222 & 2 & 0.90 & 0.065 & 0.21 & 0.434 & 1.42 & 1.9 \\
\hline $\mathrm{M}$ & 29.87 & 79 & 8 & 10.13 & 0.553 & 1.85 & 0.188 & 0.63 & 3.0 \\
\hline $\mathrm{N}$ & 32.12 & 179 & 27 & 15.08 & 1.070 & 3.33 & 0.245 & 0.76 & 3.2 \\
\hline $\mathrm{O}$ & 32.85 & 83 & 3 & 3.61 & 0.289 & 0.88 & 0.581 & 1.77 & 8.8 \\
\hline $\begin{array}{l}\text { Total } \\
\text { Ukupno }\end{array}$ & 209.78 & 1084 & 76 & 7.01 & 3.096 & 1.35 & 2.543 & 1.21 & \\
\hline
\end{tabular}

Here, the explanation could be that the delivery was made for another customer who required an allowance of only $1 \%$ (according to the older $\breve{C S N}$ ) or $5 \mathrm{~cm}$ (as is sometimes the case). When recalculating in accordance with these rules, not a single log was undersized (in Table 3, these hypothetical values are indicated in parentheses). The volume of extra allowance was $1.24 \%$, with the average allowance being $6.6 \mathrm{~cm}$ and the median $6 \mathrm{~cm}$ (Figure 10). In the graph, the deliveries are arranged according to the average of extra allowances with the goal to show possible dependence of losses (higher loss due to extra allowance versus lower loss due to moving of the log to a smaller length grade and vice versa).

\subsection{A theoretical analysis of losses}

\subsection{Teorijska analiza gubitaka}

As part of the theoretical analysis, the volumes of extra allowances were calculated depending on log mid-diameter (X-axis) and length, and expressed as a percentage of the nominal volume of the entire log. In graph 11, an excess allowance of $5 \mathrm{~cm}$ is expressed as a percentage. This allowance corresponds to the average value obtained from the actual data. Each curve represents an increase in the percentage loss of volume with increasing log diameter of the given length. The shorter the log and the larger the log diameter, the greater is the excess in volume.

Similarly, a graph could be made of the proportion of the volume of one length increment in the volume of the entire $\log$ that varies depending on the length of the $\log$ and its diameter. When moving a log to a lower length grade, diameter has a significantly greater effect on the expected volume loss than length. However, if the loss is recalculated as a percentage of the volume of the log, the length dependence is significant.

The next graph (Figure 12) shows the percentage of extra allowance volume in log volume depending on its mid- diameter (x-axis). Each colour curve corresponds to an extra allowance in centimetres. The graph was compiled for a length of $4 \mathrm{~m}$ (most of the suppliers included $4 \mathrm{~m} \operatorname{logs}$ ).

If the suppliers know or can estimate the average length of extra allowances in their deliveries, they may deduce the losses in this graph, e.g. if they usually supply $4 \mathrm{~m} \mathrm{logs}$ with an average mid-diameter of $25 \mathrm{~cm}$ and the extra allowance is $5 \mathrm{~cm}$ on average, their loss corresponds to $1.05 \%$. If they produce logs with an extra allowance of about $7 \mathrm{~cm}$, the extra allowance volume would additionally be $1.47 \%$.

\subsection{General results}

\subsection{Opći rezultati}

In terms of the volume of raw material supplied, it is more advantageous for the supplier to deliver round timber in full lengths, as the losses caused by reclassification to lower length grades do not mean as much loss as for logs.

However, suppliers of long round timber often leave allowances more than $20 \mathrm{~cm}$ longer than required. While in 2013 these extra allowances represented $1.21 \%$ in logs, in long round timber, the volume was $1.84 \%$ of the volume of wood from the analysed 
Table 3 Analysis of log deliveries in 2015

Tablica 3. Analiza isporuke trupaca u 2015.

\begin{tabular}{|c|c|c|c|c|c|c|c|c|c|}
\hline 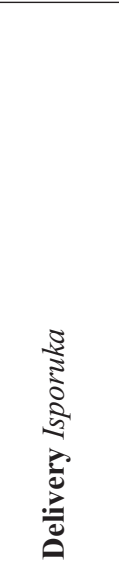 &  & 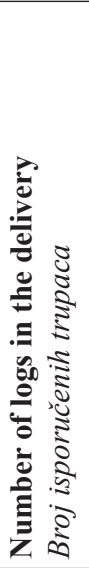 & 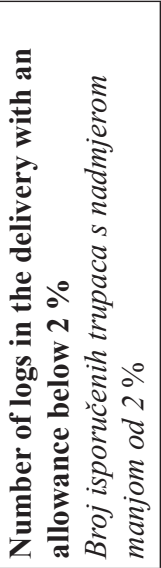 & 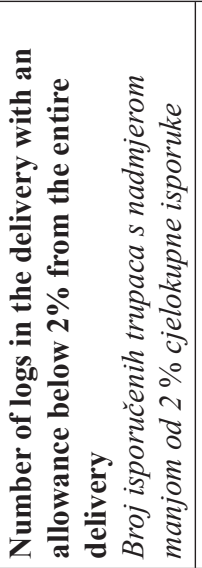 &  & 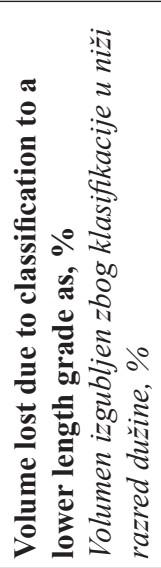 & 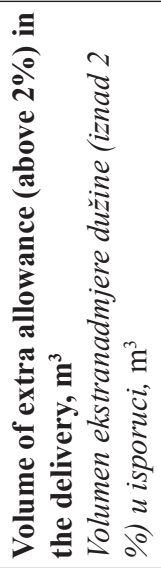 & 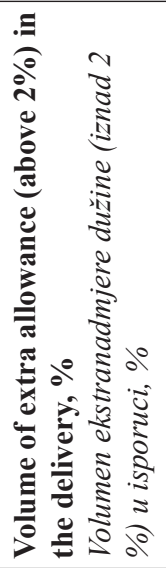 & 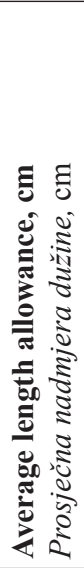 \\
\hline $\mathrm{a}$ & 31.18 & 86 & 2 & 2.33 & 0.114 & 0.37 & 0.312 & 1.00 & 6.0 \\
\hline $\mathrm{b}$ & 32.53 & 106 & 2 & 1.89 & 0.212 & 0.65 & 0.102 & 0.31 & 1.8 \\
\hline $\mathrm{c}$ & 30.69 & 107 & 1 & 0.93 & 0.095 & 0.31 & 0.249 & 0.81 & 4.9 \\
\hline $\mathrm{d}$ & 23.64 & 86 & 1 & 1.16 & 0.068 & 0.29 & 0.259 & 1.10 & 5.0 \\
\hline $\mathrm{e}$ & 24.45 & 111 & & 0.00 & 0.000 & 0.00 & 0.247 & 1.01 & 4.5 \\
\hline $\mathrm{f}$ & 26.37 & 88 & 1 & 1.14 & 0.075 & 0.28 & 0.401 & 1.52 & 6.4 \\
\hline $\mathrm{g}$ & 25.56 & 66 & 1 & 1.52 & 0.123 & 0.48 & 0.324 & 1.27 & 5.6 \\
\hline $\mathrm{h}$ & 27.97 & 116 & 4 & 3.45 & 0.303 & 1.08 & 0.116 & 0.41 & 1.7 \\
\hline $\mathrm{i}$ & 26.37 & 60 & $\begin{array}{c}7 \\
(0) \\
\end{array}$ & $11.67(0)$ & $\begin{array}{c}0.772 \\
(0)\end{array}$ & $\begin{array}{c}2.93 \\
(0) \\
\end{array}$ & $\begin{array}{c}0.082 \\
(0.328) \\
\end{array}$ & $\begin{array}{c}0.31 \\
(1.24) \\
\end{array}$ & $\begin{array}{c}2.1 \\
(6.6) \\
\end{array}$ \\
\hline $\mathrm{j}$ & 26.28 & 90 & 1 & 1.11 & 0.070 & 0.27 & 0.315 & 1.20 & 5.4 \\
\hline $\mathrm{k}$ & 26.08 & 80 & 2 & 2.50 & 0.221 & 0.85 & 0.225 & 0.86 & 3.6 \\
\hline 1 & 28.28 & 105 & & 0.00 & 0.000 & 0.00 & 0.477 & 1.69 & 6.8 \\
\hline $\mathrm{m}$ & 26.34 & 124 & 2 & 1.61 & 0.146 & 0.55 & 0.182 & 0.69 & 2.2 \\
\hline $\mathrm{n}$ & 29.25 & 34 & & 0.00 & 0.000 & 0.00 & 0.493 & 1.69 & 7.1 \\
\hline $\begin{array}{c}\text { Total } \\
\text { Ukupno }\end{array}$ & 384.99 & 1259 & 24 (17) & $1.91(1.35)$ & $\begin{array}{c}2.199 \\
(1.427) \\
\end{array}$ & $0.57(0.37)$ & $\begin{array}{c}3.782 \\
(4.028) \\
\end{array}$ & $\begin{array}{c}0.98 \\
(1.05) \\
\end{array}$ & $\begin{array}{c}4.5 \\
(4.8) \\
\end{array}$ \\
\hline
\end{tabular}



Figure 10 Comparison ("dependence") of the volume loss due to classification of the logs with undersized length to a lower length grade (dark part of the column) and volume, lost due to extra allowances (light part of the column)

Slika 10. Usporedba (,ovisnost“) gubitka volumena zbog klasifikacije trupaca premale dužine u niži razred dužine (tamni dio stupca) i volumena izgubljenoga zbog ekstranadmjere dužine (svijetli dio stupca) 


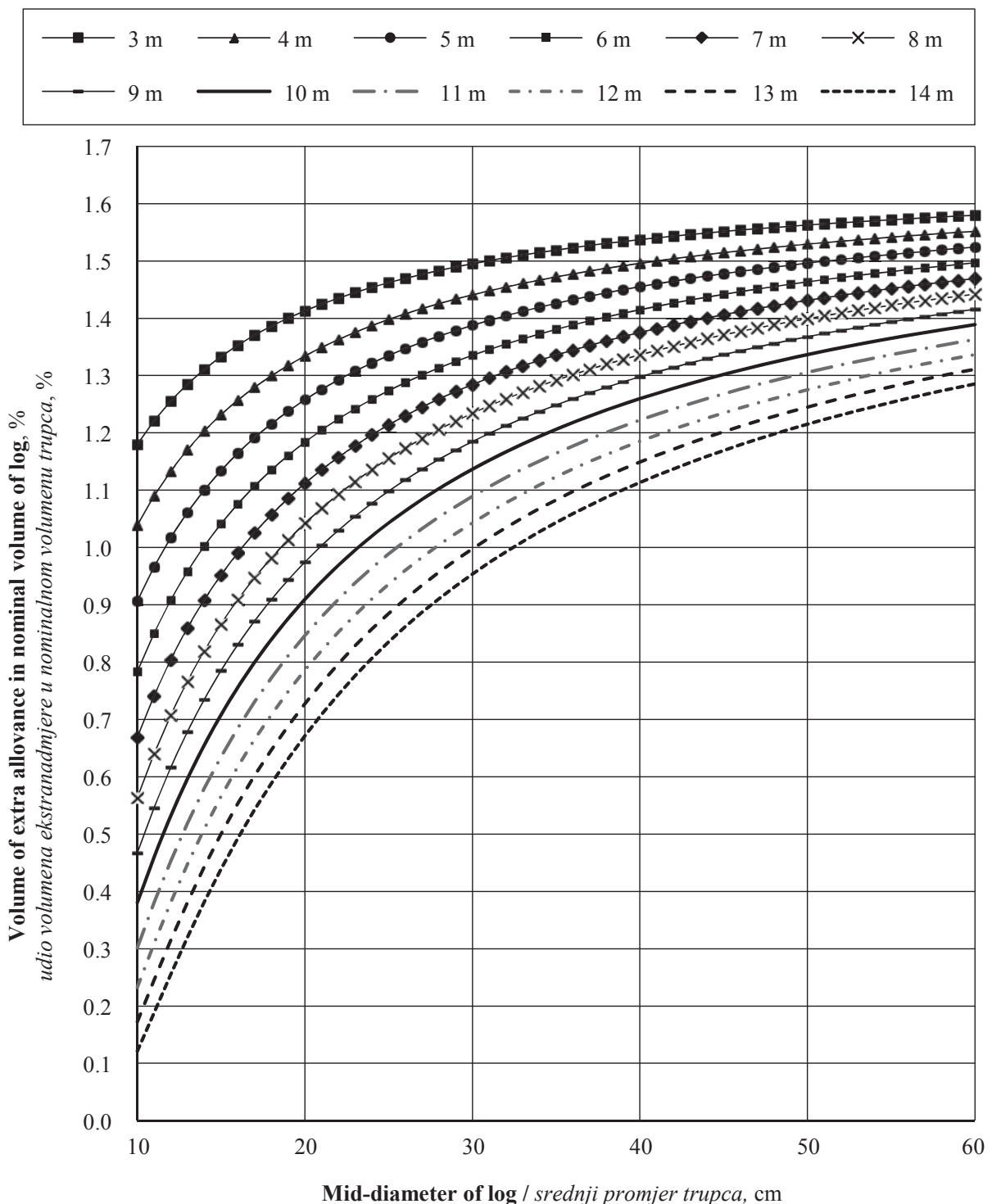

Figure 11 Proportion of volume of extra allowance in mid-diameter (course of curves) and length (single curves) of the log Slika 11. Udio volumena ekstranadmjere dužine u nominalnom volumenu trupca ovisno o srednjem promjeru (smjer krivulja) i duljini (pojedinačne krivulje) trupca

deliveries. Unfortunately, in the following years, long round timber deliveries were not analysed.

In addition, there was no noticeable difference in the average value of the allowances year-on-year - the average value ranged from 4.5 to $5.5 \mathrm{~cm}$, but the median was the same: $5 \mathrm{~cm}$. When comparing losses caused by undersized logs, there is evident development for the better, i.e. the proportion of undersized logs decreased significantly (from $7 \%$ in 2013 to $1.7 \%$ in 2018).

The results of the experimental measurements show that the most common extra allowance length was $5 \mathrm{~cm}$. In the case of deliveries with a smaller allowance, the incidence of undersized logs was higher. Conversely, for deliveries with an extra allowance close to $7 \mathrm{~cm}$ on average, the probability of reclassification was lower, and the difference in lost volume was not very noticeable when the loss in allowance and reclassification was added. In addition, an extra allowance of $5 \mathrm{~cm}$ in logs of the most common lengths was outside the permissible measuring device error of $1 \%$. Therefore, if an electronic measurement is under- estimated by the maximum permissible deviation (i.e. $5 \mathrm{~cm}$ in logs of $5 \mathrm{~m}$ in length), the log will not be marked as undersized and moved to a smaller length grade.

Furthermore, the evaluation shows that most deliveries show a loss of at least $1 \%$. The loss is either made up of only the volume of wood that is part of the extra allowance, or a combination of that volume with the volume lost due to reclassification. In the first case, the loss is less costly for the supplier. In the worst case, the supplier loses a small portion for the "fibres" that would be produced at the thinnest part of the round timber. However, this is only possible for very long units, of which more logs will be made with a larger allowance. Otherwise, it means only less of green split billet or firewood (if produced) or fewer cuttings in the forest.

In the latter case, the supplier loses more because the volume deducted upon reclassification is a volume of quality wood, the price of which normally significantly exceeds the price of the above-mentioned wood assortments. 


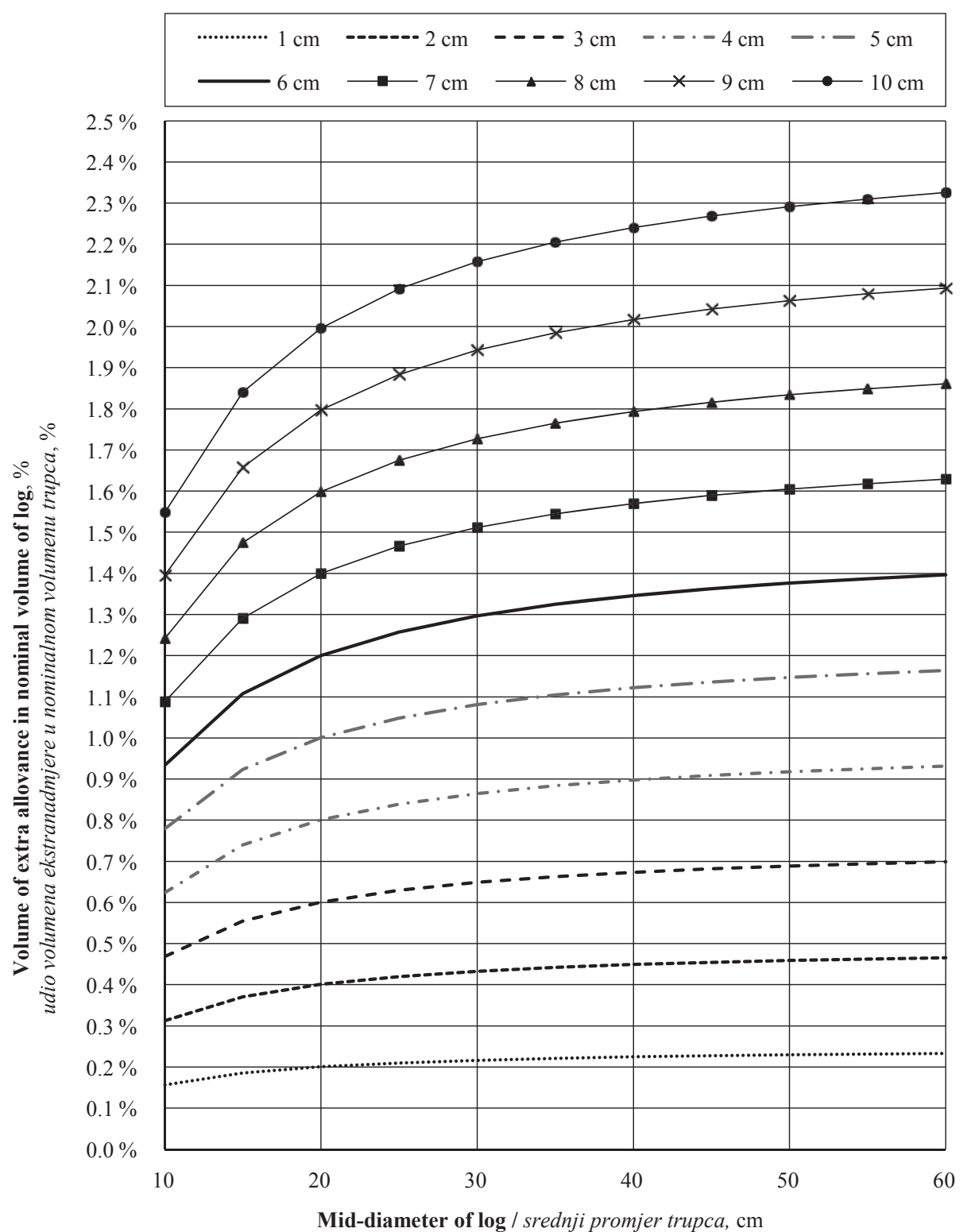

Figure 12 Proportion of extra allowance volume in log mid-diameter (course of curves) and length (single curves) of extra allowance, expressed in percentage of log volume

Slika 12. Udio volumena ekstranadmjere dužine u ukupnom volumenu trupca ovisno o srednjem promjeru trupca (smjer krivulja) i duljini trupca s ekstranadmjerom (pojedinačne krivulje), izraženo postotkom ukupnog volumena trupca

The customer wins in either case. In the case of an unnecessarily large allowance, the customer obtains raw material for the production of split billet (mostly without bark), which can be sold as raw material for other production. In the case of undersized logs, of course, the customer also has material for making split billet. However, in some cases, the cut may be left unabridged, as an addition of $1 \%$ is usually sufficient for the production of lumber of a given length. This is especially true for smaller companies where the operator can focus on individual slots.

The analysis was carried out for $1 \mathrm{~m}$ steps, which is nowadays most common in practice for saw logs. At $0.5 \mathrm{~m}$ increments, the losses would be halved. However, this also leads to a higher number of produced assortments, splitting of production and higher sorting requirements at the processor. This is only worthwhile for small sawmills.

In any case, it means a loss of quality material, which is then used for split billet or even ends up as fuel for the energy purposes of the processor.

Unfortunately, the measurements taken did not record how the logs were processed. It is therefore not possible to assess whether it was by manual production or a harvester, and whether this affected the accuracy of production. However, it can be expected that the answer is 'yes'. This factor will be examined in the next stage.

However, classification of a $\log$ into a lower length grade may affect the accuracy of the measuring equipment when used for round timber takeover. This could be the case if a log has an allowance of exactly 2 
$\%$ or only slightly larger. Only one such case emerged from the check measurements. However, not all deliveries had acceptance sheets and therefore it was not possible to detect all these cases.

During calibration measurements, $3 \%$ of all measurements were moved to a lower nominal length. However, these $3 \%$ represent $32 \%$ of the measurements of logs with an exact allowance or an allowance of only $1 \mathrm{~cm}$ larger. This shows that it would be appropriate to tolerate deviations of about $1 \mathrm{~cm}$, which corresponds to the observed average measurement accuracy. On the contrary, this is too great a risk for the supplier if the logs are cut precisely.

\section{CONCLUSIONS}

\section{ZAKLJUČAK}

The analysis was focused on length allowances with which logs are produced in the Czech Republic. For this purpose, data from check measurements carried out by suppliers in 2013 and 2015 were used, as well as data obtained from calibrations of electronic measuring devices performed by round timber customers. The volume loss represented by an allowance exceeding the required length of $2 \%$ of the length of the $\log$ was quantified. Further losses occur when there is an insufficient allowance. The log is moved to a lower length grade, so the loss corresponds to the length of this grade - in the Czech Republic, the most often used increments are $1 \mathrm{~m}$. Both losses were expressed as a percentage of the volume of the log as a whole.

Experience from calibration and an analysis of the measured data show that electronic equipment is regularly maintained and calibrated to the required accuracy. However, this may not be the case for other equipment; in case of any doubts, it would be advisable to have the measuring equipment inspected by an accredited laboratory.

The results of the analysis therefore give the following recommendations: for suppliers who do not use harvesters for felling and logging, it would be preferable to supply round timber in full lengths due to the volume lost to reclassification. Today, however, this is not possible in most cases because large customers buy only logs because of technological reasons. Another aspect is the price, which is usually higher for raw material in logs.

In the production of logs, it is preferable to increase the required $2 \%$ allowance by $4-5 \mathrm{~cm}$ if it is possible to produce logs relatively accurately. If accuracy cannot be maintained, it is preferable to increase the allowance to about $7 \mathrm{~cm}$ (e.g. mountainous terrain, poor quality and curved timber, lack of experienced staff).

\section{REFERENCES}

\section{LITERATURA}

1. Đuka, A.; Sertić, M.; Pentek, T.; Papa, I.; Janeš, D.; Poršinsky, T., 2020: Round wood waste and losses - Is rationalisation in scaling possible? Croatian Journal of Forest Engineering, 41 (2): 287-298.

https://doi.org/10.5552/crojfe.2020.770.

2. Fonseca, M. A., 2005: The measurement of roundwood. Methodologies and conversion ratio. United Nations Economic Commission for Europe, Trade and Timber Branch, Geneva, Switzerland.

3. Hunková, V.; Janák, K., 2014: Data filtration methods of electronic measurement of log dimensions. Drvna industrija, 65 (3) 205-214.

https://doi.org/10.5552/drind.2014.1339.

4. Hunková, V.; Janák, K., 2010: Methods of data filtration and their effects on the resulting image of a log at the electronic sensing its dimentisons. Acta Universitatis Agriculturae et Silviculturae Mendelianae Brunensis, 58 (1) 77-86. https://doi.org/10.11118/actaun201058010077.

5. Janák, K., 2007: Differences in round wood measurements using electronic 2D and 3D systems and standard manual method. Drvna industrija, 58 (3): 127-133.

6. Janák, K.; Ondráček, K.; Horáček, P.; Hunková, V.; Pejzl, J.; Peter, B.; Vojtová, M.; Zukal, R., 2005: Elektronické měření dřiví. Užívání elektronického měření dřiví v ČR. Kvantifikace odchylek a jejich rozbor. Přehled zahraničních metod a předpisů měření dříví. Mendel University in Brno, Brno.

7. Přibyla, A., 2005: Kvantifikace odchylek vyhodnocených rozměrů výřezů $\mathrm{v}$ závislosti na jejich poloze při snímání, bachelor thesis. Mendel university in Brno, Brno.

8. Sauter, U. H.; Staudenmaier, J.; Verhoff, S., 2010: Mehr Transparenz im Rundholzgeschäft - Elektronische Rundholzvermessung: Wie groß sind die Volumenunterschiede wirklich? Holz-Zentralblatt, 136 (50): 1260-1271.

9. Wojnar, T., 2008: Doporučená Pravidla pro Měření a Třídění Dříví v ČR 2008, $2^{\text {nd }}$ ed. Lesnická Práce s.r.o.: Kostelec nad Černými lesy, Czech Republic.

10. ***ČSN 48 0050, 1992: Surové dříví. Základní a společná ustanovení. Federální úřad pro normalizaci a měření, Praha.

11. ***ČSN EN 1309-2, 2006: Kulatina a řezivo - Metody měření rozměrů - část 2: Kulatina - Požadavky na měřní a pravidla pro výpočet objemu. Český normalizační institute, Praha.

\section{Corresponding address:}

\section{VERONIKA HUNKOVÁ, PhD}

Mendel University in Brno

Faculty of Forestry and Wood Technology

Department of Wood Science and Technology

Zemědělská 1, 61300 Brno, CZECH REPUBLIC

e-mail: veronika.hunkova@mendelu.cz 